\title{
Effect of Presoaking Sugar Beet (Beta vulgaris L.) Seeds with Gibberellic, Abscisic or Ascorbic Acids on Alleviation of Salinity Stress
}

\author{
Elsayed A. A. Abdelraouf ${ }^{1}$
}

\begin{abstract}
A study was conducted to investigate the effect of presoaking of sugar beet (Beta vulgaris L.) seeds (polygerm) with gibberellic acid, abscisic acid, or ascorbic acid on alleviation of salt stress at seedling stage. The salinity levels of irrigation solution were $0,25,50$ and 100 $\mathrm{mM} \mathrm{NaCl}$ and the presoaking treatments were water as a control, $10 \mu \mathrm{M} \mathrm{GA3}, 10 \mu \mathrm{M}$ ABA, and $0.5 \mathrm{mM}$ ASA for 12 hrs. Seeds were sown in plastic pot containing $0.8 \mathrm{Kg}$ prewashed sand and irrigated three times weekly by $100 \mathrm{~mL}$ per pot of one-tenth modified Hoagland solution containing the salt level. After seven weeks from sowing, the whole plants were collected. The results indicated that increasing salt concentration decreased the fresh and dry weight of whole plant, shoot and root, and shoot height of all presoaking treatments. However, shoot/root ratio on fresh and dry weight basis and moisture content of whole plant, shoot and root, chlorophyll content index, and electrolyte leakage were increased with increasing salt concentration of all presoaking treatments. However, presoaking of sugar beet seeds (polygerm) with the GA3, ABA, or ASA showed no significant effect to alleviation salt stress on sugar beet seedlings. However, the interaction between salt levels and presoaking treatments was significant for whole plant and root fresh and dry weights, shoot/root ratio on fresh weight basis, whole plant and root moisture content and chlorophyll content index, while nonsignificant for shoot fresh and dry weights, shoot height, shoot/root ratio on dry weight basis, shoot moisture content and electrolyte leakage.
\end{abstract}

Keywords: Salt stress, sugar beet, gibberellic acid, abscisic acid, ascorbic acid, presoaking.

\section{INTRODUCTION}

Salinity in soil or water is one of the major abiotic stress especially in arid and semi- arid regions and can severely limit crop production (Shannon, 1998). The high salt concentrations interfere with seed germination and crop establishment (Fowler, 1991). Germination and seedling characteristics are the most viable criteria used for selecting salt tolerance in plants (Boubaker, 1996). Salinity stress can affect seed germination through osmotic effects (Welbaum et al., 1990). Sugar beet (Beta vulgaris L.), a member of the Chenopodiaceae, is a long-day biennial plant grown almost exclusively as a source of sucrose. However, following sucrose extraction, the plant pulp often enriched with molasses that provides a high energy animal feed. Except for

\footnotetext{
${ }^{1}$ Department of Natural Resources and Agricultural Engineering, Damanhur University, Egypt.

Received February 21, 2017, Accepted March 26, 2017
}

during the early growth stages following stand establishment, the plant is quite tolerant to salinity (Katerji et al., 1997). It has been reported that sugar beet yield decrease is 0 percent at an ECe of $7 \mathrm{dS} / \mathrm{m}, 50$ percent at ECe of $15 \mathrm{dS} / \mathrm{m}$, and 100 percent at ECe of $24 \mathrm{dS} / \mathrm{m}$ (Ayers and Westcot, 1985). However, during early growth stages of sugar beet the ECe should not exceed $3 \mathrm{dS} / \mathrm{m}$ (Steduto et al., 2012). It has been reported that presoaking of seed with optimal concentration of plant hormones and growth regulators have been used intensively for increasing salt-tolerance of plants (Plaut et al., 2013).

Ascorbic acid (ASA) is regarded as one of the most effective growth regulators against abiotic stresses especially high salinity (Batool el al., 2012). Azooz et al. (2013) showed that application of ascorbic acid through seed soaking enhanced plants growth by increasing germination percentage, root and shoot fresh and dry weights, chlorophyll content and osmolytes accumulation. They found that pretreatment with ASA reduced salt induced adverse effects and resulted in a significant increment of growth and yield.

Gibberellic Acid (GA3) is the most important growth hormone which increases cell growth and elongation, promotes seed germination, increases the size of leaves that enables greater photosynthesis and plant metabolism and ultimately increases plant or crop yield under normal as well as stress condition. GA3 is used to revive the plants suffering from salt stress by overcoming the adverse effects of the salt stress on germination (Amal and Heba, 2014). Jamil and Rha (2007) reported that soaking sugar beet seeds with GA3 alleviated the adverse effect of salt stress on plant growth expressed in terms of roots and shoots lengths and fresh weights. Gibberellic acid and Kinetin have been reported to increase percentage germination and seedling growth (Kaur et al., 1998).

Hence, the present study was carried out in order to investigate the effectiveness of three growth stimulators (GA3, ABA or ASA) on ameliorating the adverse effect of salinity stress on sugar beet during early growth stage.

\section{MATERIALS AND METHODS}

A pot experiment was carried out during March 2016 at Etay Elbaroud Agric. Res. Center, Ministry of Agriculture and Land Reclamation (MALR), El Beheira 
Governorate, Egypt to investigate the effect of presoaking of seeds of sugar beet (Beta vulgaris L., cv. Gazelle, polygerm) imported from Denmark with gibberellic acid (GA3), abscisic acid (ABA), ascorbic acid (ASA), or distilled water on alleviation salt stress. A randomized complete block design in a split-plot array with three replicates was used. The main plot was salt levels $(0,25,50$ and $100 \mathrm{mM} \mathrm{NaCl})$ and the subplot was presoaking treatments (distilled water as a control, $10 \mu \mathrm{M} \mathrm{GA} 3,10 \mu \mathrm{M}$ ABA, and $0.5 \mathrm{mM}$ ASA). Sugar beet seeds were soaked for 12 hours in water, GA3, ABA and ASA solutions after that 10 seeds were sown in plastic pots of $12 \mathrm{~cm}$ diameter and $9 \mathrm{~cm}$ depth, with holes in the bottom for drainage of excess water, containing $0.8 \mathrm{Kg}$ pre-washed quartz sand of size fraction between 0.25 and $1 \mathrm{~mm}$ (Hewitt, 1966). Each pot was irrigated three times per week with $100 \mathrm{~mL}$ of irrigation solution. The irrigation solution contains both one-tenth strength modified Hoagland and Arnon nutrient solution (Hewitt, 1966), and the tested salt levels $(0,25,50$ or $100 \mathrm{mM} \mathrm{NaCl})$. The concentrations of macronutrients in the irrigation solution were 16.87 , $8.47,11.92,29.99,12.00,4.78$, and $6.38 \mathrm{mg} \mathrm{L}^{-1}$ for $\mathrm{N}$ $\mathrm{NO}_{3}, \mathrm{~N}-\mathrm{NH}_{4}, \mathrm{P}, \mathrm{K}, \mathrm{Ca}, \mathrm{Mg}$, and $\mathrm{S}$, respectively. The concentrations of micronutrients in the irrigation solution were $0.50,0.11,0.05,0.01,0.01$ and $0.005 \mathrm{mg}$ $\mathrm{L}^{-1}$ for $\mathrm{Fe}, \mathrm{Mn}, \mathrm{B}, \mathrm{Zn}, \mathrm{Cu}$ and $\mathrm{Mo}$, respectively (Hewitt, 1966). The number of plants per pot was kept to four thinned 14 days after sowing.

The chlorophyll content index of fully expanded leaves were measured by the chlorophyll meter device (SPAD-502, Minolta, Japan) before collecting plants. After seven weeks from sowing, the whole plants were collected. The fresh seedlings were subjected to washing by tap water then by distilled water (Hewitt, 1966). The seedlings were then separated into shoots and roots and the fresh weight of shoots and roots and shoot height were measured.

The membrane damage was assessed by measuring the leakage of electrolytes from leaf discs according to Mishra and Choudhuri, (1999), where leaf discs (10 mm in diameter) were cut from the leaf blade, avoiding major veins, and thoroughly rinsed, placed in $2 \mathrm{ml}$ of distilled water and kept in the dark for $24 \mathrm{hrs}$ before measuring the electrical conductivity of the solution which was carried out by JENWAY 4510 Conductivity Meter.

The plant samples were then dried at $70 \square \mathrm{C}$ for 48 hours and the dry weight of shoots and roots were measured. The shoot/root ratio, on fresh and oven-dried weight basis, was calculated.

The obtained results were submitted to analysis of variance using the CoStat statistical analysis software
(CoStat 6.400). Differences among means were identified using Fisher's Least Significant Difference (LSD) test at the 0.05 probability level.

\section{RESULTS AND DISCUSSION}

\section{Growth of whole plant}

Table 1 showed that increasing salt concentration from zero to $100 \mathrm{mM} \mathrm{NaCl}$ significantly $(\mathrm{p}<0.01)$ decreased the whole fresh weight of sugar beet seedlings. The values of the relative decrease were in the order; 4.9, 31.3 and $41.4 \%$ for 25,50 , and $100 \mathrm{mM}$ $\mathrm{NaCl}$ levels, respectively as compared to the control $(0$ $\mathrm{mM} \mathrm{NaCl}$ ). On the other hand, the whole plant fresh weight insignificantly affected by the different presoaking treatments under different salt levels. The interaction between salt levels and presoaking treatments was significant $(\mathrm{p}<0.01)$ with respect to whole plant fresh weight (Fig. 1). The highest whole plant fresh weight $(2.74 \mathrm{~g} /$ plant $)$ was obtained at $25 \mathrm{mM}$ $\mathrm{NaCl}$ and presoaking with ASA while the lowest value $(1.33 \mathrm{~g} /$ plant $)$ was obtained at $100 \mathrm{Mm} \mathrm{NaCl}$ and presoaking with water. Increasing salinity levels significantly $(\mathrm{p}<0.01)$ decreased the whole plant dry weight of sugar beet seedlings with all presoaking treatments (Table 1). The mean values of relative decrease, with respect to whole plant dry weight, under all presoaking treatments and with increasing salinity levels, were $11.3,32.5$, and $48.3 \%$ at 25,50 , and 100 $\mathrm{mM} \mathrm{NaCl}$, respectively compared to the control. It is clear, therefore, that the presoaking treatments had no significant effect on whole plant dry weight under different salinity levels. However, the interaction between salinity levels and presoaking treatments had significant $(p<0.05)$ effect on the whole plant dry weight of sugar beet seedlings (Fig. 2). The highest whole plant dry weight $(0.41 \mathrm{~g} /$ plant $)$ was obtained with $0 \mathrm{mM} \mathrm{NaCl}$ and presoaking with water (the control treatment) while the lowest value $(0.18 \mathrm{~g} / \mathrm{plant})$ was obtained with $100 \mathrm{mM} \mathrm{NaCl}$ and presoaking with water.

\section{Growth of shoots}

Increasing salt concentration (more than $25 \mathrm{mM}$ $\mathrm{NaCl})$ decreased significantly $(\mathrm{p}<0.05)$ the shoot fresh weight of all presoaking treatments (Table 1). The values of relative decrease in shoot fresh weight with increasing salinity levels of all presoaking treatments were 7.7 , and $14.1 \%$ with 50 , and $100 \mathrm{mM} \mathrm{NaCl}$, respectively as compared to the control. However, there were no significant differences between presoaking treatments with respect to shoot fresh weight under different salt levels. Moreover, there were also no significant differences, with respect to shoot fresh weight between the interaction of salinity and presoaking treatments. 
Table 1 showed that shoot dry weight of sugar beet seedlings decreased significantly $(\mathrm{p}<0.01)$ with the increase of salt concentrations with all presoaking treatments, since the values of relative decrease, in shoot dry weight due to increasing salinity levels of all presoaking treatments, were $2.2,12.1$, and $21.5 \%$ at 25 , 50 , and $100 \mathrm{mM} \mathrm{NaCl}$, respectively as compared to the control. On the other hand, there were no significant differences between presoaking treatments with respect to shoot dry weight under salt stress. In addition, there were also no significant differences were observed between the interaction of salinity and presoaking treatments with respect to shoot dry weight.

\section{Growth of roots}

Increasing salt concentration decreased significantly $(p<0.01)$ the root fresh weight of sugar beet seedlings with all presoaking treatments (Table 1 and Fig. 3). The mean values of relative decrease, in root fresh weight due to increasing salinity with all presoaking treatments, were $14.6,55.2$, and $69.3 \%$ at 25,50 , and $100 \mathrm{mM}$ $\mathrm{NaCl}$, respectively as compared to the control. It is also clear that presoaking treatments had no significant effect on root fresh weight of sugar beet seedlings under different salinity levels. However, the interaction between salinity and presoaking treatments had significant effect $(\mathrm{p}<0.01)$ on root fresh weight, where the highest weight (1.53 $\mathrm{g}$ fresh root/plant) was obtained with $0 \mathrm{mM} \mathrm{NaCl}$ and presoaking with water (the control) while the lowest weight $(0.33 \mathrm{~g}$ fresh root/plant $)$ was obtained with $100 \mathrm{mM} \mathrm{NaCl}$ and presoaking with ABA.

Table 1. The growth characters of sugar beet as influenced by salinity levels and different presoaking treatments

\begin{tabular}{|c|c|c|c|c|c|c|c|c|}
\hline \multirow[t]{2}{*}{ Treatment } & \multicolumn{3}{|c|}{ Fresh weight $\left(\right.$ g plant $\left.^{-1}\right)$} & \multicolumn{3}{|c|}{ Dry weight (g plant $\left.{ }^{-1}\right)$} & \multicolumn{2}{|c|}{ Shoot/Root ratio } \\
\hline & Whole & Shoot & Root & Whole & Shoot & Root & F. W. & D. W. \\
\hline \multicolumn{9}{|c|}{ Salinity levels (mM NaCl) } \\
\hline 0 & 2.40 & 1.21 & 1.19 & 0.37 & 0.16 & 0.20 & 1.09 & 0.80 \\
\hline 25 & 2.28 & 1.27 & 1.02 & 0.32 & 0.16 & 0.17 & 1.29 & 0.96 \\
\hline 50 & 1.65 & 1.12 & 0.53 & 0.25 & 0.14 & 0.10 & 2.25 & 1.38 \\
\hline 100 & 1.41 & 1.04 & 0.37 & 0.19 & 0.13 & 0.06 & 2.93 & 2.06 \\
\hline LSD & 0.12 & 0.12 & 0.11 & 0.03 & 0.01 & 0.02 & 0.43 & 0.13 \\
\hline \multicolumn{9}{|c|}{ presoaking treatments } \\
\hline Water & 1.93 & 1.12 & 0.80 & 0.29 & 0.15 & 0.14 & 1.97 & 1.30 \\
\hline GA3 & 1.85 & 1.12 & 0.73 & 0.27 & 0.14 & 0.13 & 1.79 & 1.27 \\
\hline $\mathrm{ABA}$ & 1.97 & 1.17 & 0.80 & 0.28 & 0.15 & 0.13 & 1.92 & 1.30 \\
\hline ASA & 2.00 & 1.23 & 0.77 & 0.28 & 0.15 & 0.13 & 1.87 & 1.33 \\
\hline LSD & $\mathrm{ns}$ & $\mathrm{ns}$ & ns & $\mathrm{ns}$ & $\mathrm{ns}$ & $\mathrm{ns}$ & $\mathrm{ns}$ & ns \\
\hline
\end{tabular}

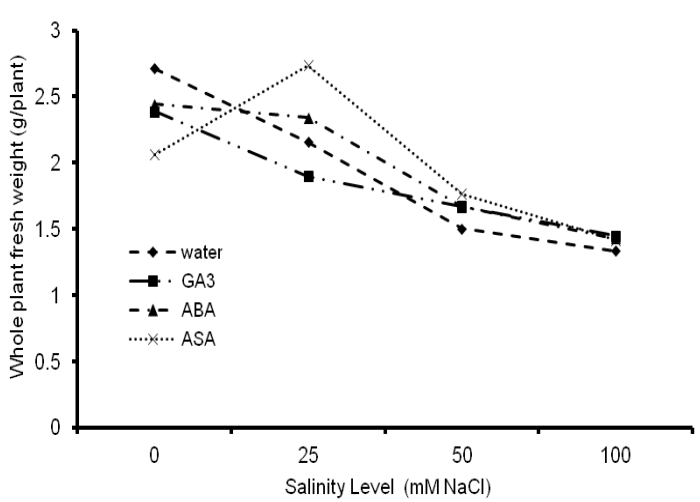

Fig. 1. The relation between salinity levels and the whole plant fresh weight of sugar beet with different presoaking treatments

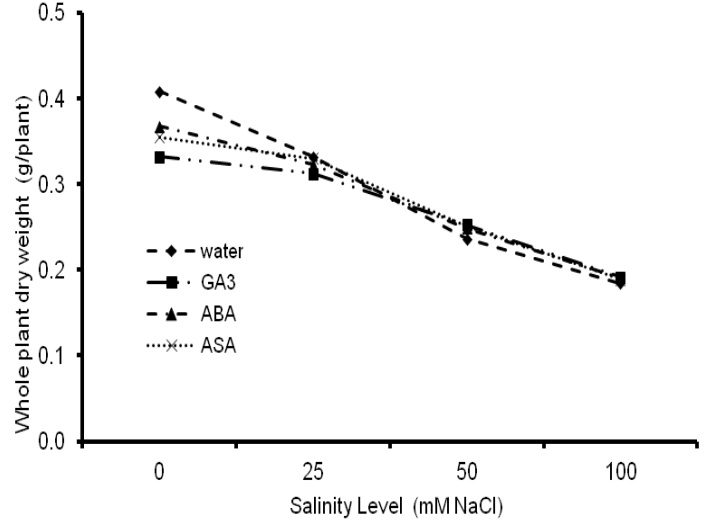

Fig. 2. The relation between salinity levels and the whole plant dry weight of sugar beet with different presoaking treatments 


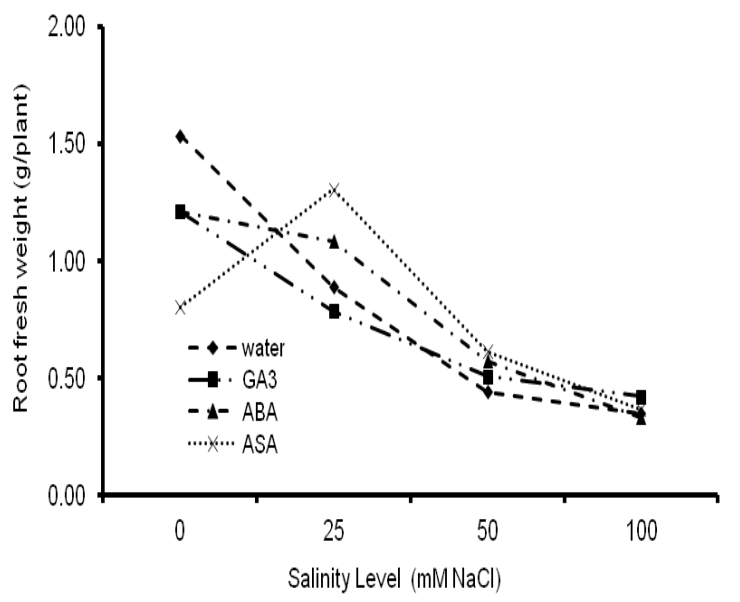

Fig. 3. The relation between salinity levels and the root fresh weight of sugar beet at different presoaking treatments

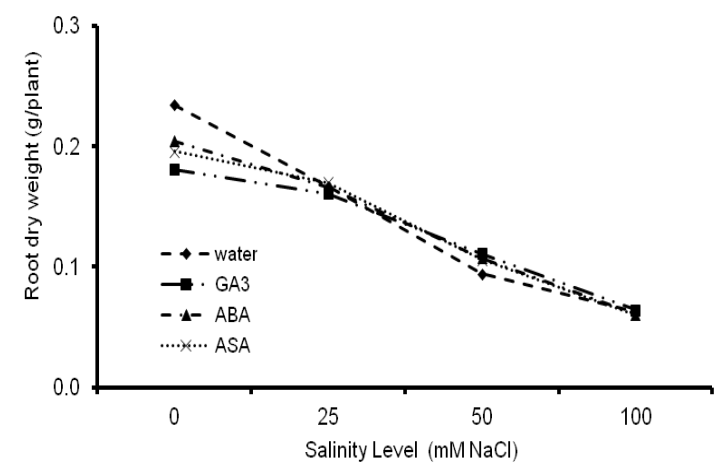

Fig. 4. The relation between salinity levels and the root dry weight of sugar beet at different presoaking treatments

The root dry weight of sugar beet seedlings decreased significantly $(\mathrm{p}<0.01)$ with increasing salt concentrations in the irrigation solution (Table 1 and Fig. 4). The mean value of relative decrease, in root dry weight due to increasing salinity with all presoaking treatments, were $18.6,48.7$, and $69.6 \%$ at 25,50 , and $100 \mathrm{mM} \mathrm{NaCl}$, respectively as compared to the control. On the other hand, there were no significant differences between presoaking treatments with respect to root dry weight under different salt levels. However, there were significant differences $(p<0.01)$ between the interaction of salinity and presoaking treatments on root dry weight. The highest root dry weight $(0.23 \mathrm{~g}$ dry root/plant $)$ was obtained with $0 \mathrm{mM} \mathrm{NaCl}$ and presoaking with water while the lowest weight (0.06 g dry root/plant) was obtained with $100 \mathrm{mM} \mathrm{NaCl}$ and with all presoaking treatments.
The obtained results are in agreement with found by Al-sahil, (2016), who found that seed presoaking treatments of cucumber with gibberellic and salicylic acids were recorded nonsignificant for seedling length, fresh and dry weights under induced salt stress. Jamil and Rha (2007) found that increase in salt concentrations of the growth medium of sugar beet caused a significant reduction in mean fresh weights of whole plant, roots and shoots, while soaking plant seeds with GA3 had alleviated the adverse effect of salt stress. The depressive effect of salinity on plant growth is probably due to osmatic inhibition of water absorption, accumulation of certain ions in high concentration in plant tissues and alteration of the mineral balance of plants (Khafagi and El-Lawandy, 1996), and/or due to the reduction in photosynthetic activity and carbohydrates metabolism (Heuer and Plaut, 1989). The decrease in dry matter accumulation is mainly due to increase in $\mathrm{Na}^{+}$and $\mathrm{Cl}^{-}$under high salt stress causing a reduction in the activity of $\mathrm{CO}_{2}$-fixation during photosynthesis and a decrease in the enzymatic activity of the metabolic processes (Ahmed, 1987).

\section{Shoot/root ratio}

Increasing salt concentrations significantly $(p<$ 0.01 ) increased shoot/root ratio on both fresh and dry weight basis (Table 1), while there were no significant effect due to different presoaking treatments on shoot/root ratio on both fresh and dry weight basis under all salinity levels. However, the interaction between salinity and presoaking treatments showed significant effect $(\mathrm{p}<0.05)$ on fresh weight basis but not on dry weight basis. Increasing values of shoot/root ratio with increasing salinity levels indicating that the reduction in root growth was greater than that in shoot. This indicates that roots of sugar beet had adversely affected by salinity more than shoots. It is also clear that the values of shoot/root ratio were higher on fresh weight basis than on dry weight basis. This is due to higher water content in shoots than in roots. These results agree with found by Jamil et al. (2006) who reported that salt stress inhibited the growth of roots more than shoots of sugar beet. Demir and Arif (2003) obtained very close results with respect to the effect of salinity on seedling growth of safflower.

\section{Shoot height}

Increasing salt concentrations significantly $(\mathrm{p}<0.01)$ decreased the shoot height of sugar beet seedlings with all presoaking treatments (Table 2). The mean value of relative decrease in shoot height with increasing salinity were $9.6,12.7$, and $20.6 \%$ at 25,50 , and $100 \mathrm{mM} \mathrm{NaCl}$, respectively as compared to the control. On the other hand, there were significant differences between presoaking treatments with respect 
to shoot height under salt levels. However, there were no differences between the interaction of salinity and presoaking treatments on shoot height. Jamil and Rha (2007) found that the increase of salt concentration in the growth medium of sugar beet caused a strong inhibition of the average length of root and shoot due to all treatments with or without GA3.

\section{Moisture content}

Increasing salt concentrations treatments significantly $(\mathrm{p}<0.05)$ increased whole plant moisture content (Table 2). Also, there were significant effect ( $p$ $<0.01$ ) of salinity and presoaking interaction on whole plant moisture content (Fig. 5). However, there were no significant effect of presoaking treatments on whole plant moisture content under the studied salt levels. Also, increasing salinity significantly $(\mathrm{p}<0.01)$ increased shoot moisture content of sugar beet seedlings with all presoaking treatments (Table 2). Moreover, there were significant effect $(p<0.05)$ of presoaking treatments on shoot moisture content under the tested salt levels, while there were no differences for shoot moisture content between the interaction of salinity and presoaking treatments. On the other hand, increasing salt levels had no significant effect on root moisture content with all presoaking treatments, and also presoaking treatments had no significant effect on root moisture content under increasing salt levels. However, the interaction between salt concentrations and presoaking treatments had significant effect on root moisture content (Fig. 6).

As shown in Table 2 the moisture content in shoots was almost higher than in roots. Thus, it is clear that as salt level increases moisture contents of whole plant, shoot and root of sugar beet seedlings were increased. These data indicate that sugar beet plant can tolerate the adverse effects of salt stress by increasing its succulence. This means that the plant had increased both shoot and root volumes by increasing their moisture contents more than its effect on dry the biomass content as a result of increasing salt levels. These results are in agreement with those reported by Elsokkary et al. $(2010,2011)$ who found that treatment of pea plant grown in sand culture under salinity stress by gibberellic acid had increased the moisture content in the plant. Also, Elsayed et al. (2016) who reported that increasing salinity increased moisture content of different broad bean cultivars.

\section{Chlorophyll content index}

Increasing salt concentrations increased significantly $(\mathrm{p}<0.01)$ chlorophyll content index in leaves of sugar beet seedlings with all presoaking treatments (Table 2). The mean values relative increase in chlorophyll content index of all presoaking treatments with increasing salt levels were $8.2,26.8$, and $43.7 \%$ at 25, 50, and $100 \mathrm{mM}$ $\mathrm{NaCl}$, respectively as compared to the control. However, presoaking treatments had no significant effect on chlorophyll content index under salt stress. The interaction between salt levels and presoaking treatments had significant effect $(\mathrm{p}<0.01)$ on chlorophyll content index (Fig. 7). The highest chlorophyll content index value (49.4 SPAD) was obtained with $100 \mathrm{mM} \mathrm{NaCl}$ and presoaking with GA3, while the lowest value (32.9 SPAD) was obtained with 0 $\mathrm{mM} \mathrm{NaCl}$ and presoaking with ASA. These results are in agreement with those reported by Dadkhah (2011) who found that leaf chlorophyll content of two sugar beet cultivars increased with increasing salinity. Nieman (1962) observed that plant species differed in their response to salinity with respect to chlorophyll content in plant leaves of turnip and cabbage where chlorophyll content had increased due to salinity while in wheat, increasing salinity decreased total chlorophyll content.

Table 2. The shoot height, chlorophyll content index, electrolyte leakage and moisture contents of sugar beet as influenced by salinity levels and presoaking treatments

\begin{tabular}{|c|c|c|c|c|c|c|}
\hline \multirow[b]{2}{*}{ Treatment } & \multirow{2}{*}{$\begin{array}{l}\text { Shoot height } \\
(\mathrm{cm})\end{array}$} & \multicolumn{3}{|c|}{ Moisture content (\%) } & \multirow{2}{*}{$\begin{array}{l}\text { Chlorophyll } \\
\text { content index } \\
\text { (SPAD value) }\end{array}$} & \multirow{2}{*}{$\begin{array}{c}\text { Electrolyte } \\
\text { leakage } \\
\left(\mu \mathrm{Scm}^{-1}\right)\end{array}$} \\
\hline & & Whole & Shoot & Root & & \\
\hline \multicolumn{7}{|c|}{ Salinity levels (mM NaCl) } \\
\hline 0 & 6.94 & 84.7 & 86.6 & 82.1 & 33.9 & 200.4 \\
\hline 25 & 6.28 & 85.6 & 87.4 & 83.0 & 36.7 & 891.8 \\
\hline 50 & 6.06 & 85.0 & 87.3 & 79.3 & 43.0 & 1737.5 \\
\hline 100 & 5.51 & 86.5 & 87.8 & 82.7 & 48.7 & 2424.3 \\
\hline LSD & 0.52 & 0.9 & 0.5 & $\mathrm{~ns}$ & 2.5 & 544.6 \\
\hline \multicolumn{7}{|c|}{ Presoaking treatments } \\
\hline Water & 6.16 & 85.0 & 86.6 & 80.8 & 41.4 & 1050.7 \\
\hline GA3 & 6.22 & 85.3 & 87.2 & 81.8 & 39.6 & 1581.5 \\
\hline $\mathrm{ABA}$ & 6.25 & 85.7 & 87.4 & 82.2 & 40.3 & 1209.1 \\
\hline ASA & 6.16 & 85.8 & 87.8 & 82.2 & 41.0 & 1412.9 \\
\hline LSD & $\mathrm{ns}$ & ns & 0.7 & ns & ns & $\mathrm{ns}$ \\
\hline
\end{tabular}




\section{Membrane damage}

Increasing salt levels in the growth medium increased significantly $(\mathrm{p}<0.01)$ membrane damage where the leakage of electrolyte from the leaf cells were increased by increasing salinity with all presoaking treatments (Table 2). The mean values of relative increase in electrolyte leakage of all presoaking treatments with increasing salinity were 345.0, 767.0, and $1109.7 \%$ at 25,50 , and $100 \mathrm{mM} \mathrm{NaCl}$, respectively as compared to the control. However, there were no significant effect of presoaking treatments on membrane damage under salt stress. Also, there were no significant effect of the interaction between salt levels and presoaking treatments on membrane damage of sugar beet seedlings. Salt stress induced electrolyte leakage has been previously observed in maize (Hichem et al., 2009). Very close results were obtained in tomato by Kaya et al. (2001a) and in cucumber and pepper Kaya et al. (2001b).

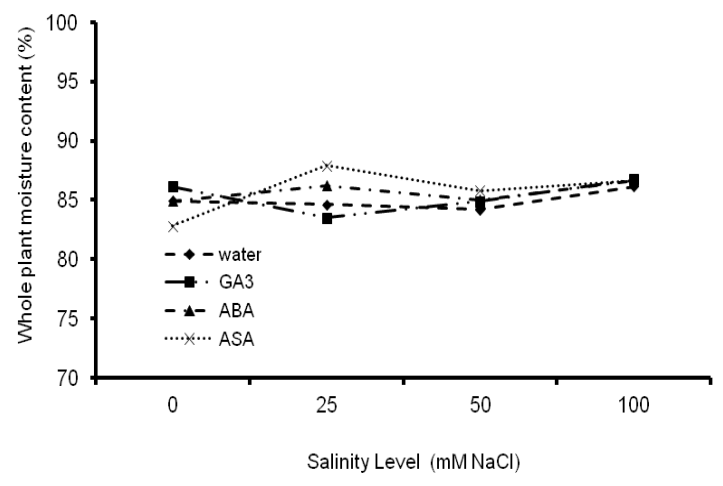

Fig. 5. The relation between salinity levels and the whole plant moisture content of sugar beet at different presoaking treatments

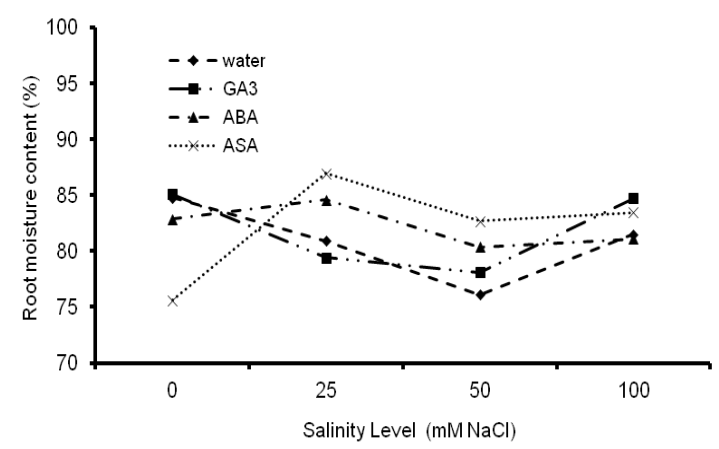

Fig. 6. The relation between salinity levels and the root moisture content of sugar beet at different presoaking treatments

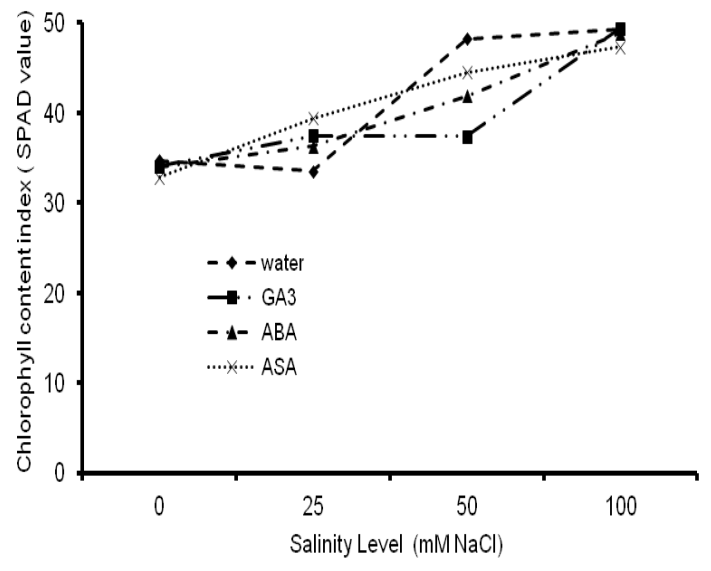

Fig. 7. The relation between salinity levels and the chlorophyll content index of sugar beet at different presoaking treatments

\section{CONCLUSION}

Increasing salinity stress decreased growth parameters of sugar beet (Beta vulgaris L., cv. Gazelle) at seedling growth stage. However, the shoot/root ratio, moisture content of both whole plant, shoot and root, chlorophyll content index and electrolyte leakage were increased with increasing salt concentration of all presoaking treatments. Presoaking polygerm seeds of Gazelle sugar beet cultivar with each of growth regulator (GA3, ABA or ASA) at the studied concentrations and time of soaking had no significant effect on alleviation of salinity stress on seedlings. On the other hand, the interaction between salinity stress and presoaking treatments was significant for whole plant and root fresh and dry weights, shoot/root ratio on fresh weight basis, whole plant and root moisture content and chlorophyll content index, while nonsignificant for shoot fresh and dry weights, shoot height, shoot/root ratio on dry weight basis, shoot moisture content and electrolyte leakage.

\section{REFERENCES}

Abdelraouf, E.A.A., I.A.A. Adss and M.Z. Dakroury. 2016 Effect of Salinity on Growth and Genetic Diversity of Broad Bean (Vicia faba L.) Cultivars. Alex. Sci. Exch. J. 37 (3): 467-479.

Ahmed, A.M., 1987. Effect of saline irrigation water, Nfertilization and supplemental foliar spraying with $\mathrm{K}$ and $\mathrm{Mg}$ on growth, nutritional status and yield of sugar beet in desert calcareous soil. Desert Inst. Bull. Egypt. 37 (2): 219-239. 
Al-sahil, A. A., 2016. Effect of gibberellic and salicylic acids pre-soaking on seed germination attributes of cucumber (Cucumis sativus L.) under induced salt stress. Cercetări Agronomice în Moldova. Vol. XLIX, No. 1 (165) / 2016: 99-109.

Amal, M.E.A. and I.M. Heba. 2014. The effect of the exogenous gibberellic acid on two salt stressed barley cultivars. Europ. Sci. J., 10(6).

Ayers, R.S. and D.W. Westcot. 1985. Water quality for agriculture; FAO Irrigation and Drainage Paper. 29 Rev. 1. FAO, Rome.

Azooz, M.M., A.M. Alzahrani, and M.M. Youssef. 2013. The potential role of seed priming with ascorbic acid and nicotinamide and their interactions to enhance salt tolerance in broad bean (vicia faba L.). Aust. J. Crop Sci. 7(13): $2091-2100$.

Batool, E.J.A.Z., Z.A. Sajid, and F. Aftab. 2012. Effect of exogenous application of ascorbic acid on antioxidant enzyme activities, proline contents, and growth parameters of Saccharum spp. hybrid cv. HSF-240 under salt stress. Turkish J. Biol. 36(6), 630-640.

Boubaker M. 1996. Salt tolerance of durum wheat cultivars during germination and early seedling growth, Agric. Medit. 126: 32-39.

CoStat. 2005. Cohort Software. 798 Lighthouse Ave., PMB 320 Monterey, USA.

Dadkhah, A. 2011. Effect of salinity on growth and leaf photosynthesis of two sugar beet (Beta vulgaris L.) cultivars. J. Agr. Sci. Tech. 13: 1001-1012.

Demir, M. and I. Arif. 2003. Effects of different soil salinity levels on germin ation and seedling growth of safflower (Carthamus tinctorius L.), Turk. J. Agric. 27: 221-227.

Elsokkary, I.H., A.Y. Mourad, A. Abdelhady and E.A. Abdallah. 2010. Response of pea (Pisum sativum L.) plant grown in sand culture under salinity stress to foliar application by kinetin and gibberellic acid. J. Soil Sci. Agric. Engin., Mansoura Univ. 1 (11): 1075 - 1087.

Elsokkary, I.H., E.A. Abdallah, A.Y. Mourad and A. Abdelhady. 2011. Influence of salt stress on the growth, elements contents and antioxidative enzymes activities of pea (Pisum sativum L.) plant grown in sand culture. J. Soil Sci. Agric. Engin., Mansoura Univ. 2 (5): 509 - 525.

Fowler, J.L. 1991. Interaction of salinity and temperature on the germination of Crambe, Agron. J. 83: 169-172.

Heuer, B. and Z. Plaut. 1989. Photosynthesis and osmotic adjustment of two sugar beet cultivars grown under saline conditions. J. Exper. Bot. 40 (213): 437 - 440.

Hewitt, E. G. 1966. Sand and Water Culture Methods Used in the Study of Plant Nutrition. Technical Communication No. 22. 2nd ed. Commonwealth Agricultural Bureaux, Fornham Royal, England.
Hicham, H., D. Mounir and E. Naceur. 2009. Differential responses of two maize (Zea mays L.) varieties to salt stress: Changes on polyphenols composition of foliage and oxidative damages. Ind. Crop Prod. 30: $144-151$.

Jamil, M., D.B. Lee, K.Y. Jung, M. Ashraf, S.C. Lee, and E.S. Rha, 2006. Effect of salt $(\mathrm{NaCl})$ stress on germination and early seedling growth of four vegetables species. J. Central Europ. Agric. 7 (2): 273-282.

Jamil, M. and E.S. Rha., 2007. Gibberellic acid (GA3) enhance seed water uptake, germination and early seedling growth in sugar beet under salt stress. Pakistan J. Biol. Sci. 10(4): $654-658$.

Katerji, N., J.W. van Hoorn, A. Hamdy, M. Mastrorilli and E. Muo Karzel. 1997. Osmotic adjustment of sugar beets in response to soil salinity and its influence on stomatal conductance, growth and yield. Agric. Water Manag. 34: 57-69.

Kaur, S., A.K. Gupta and N. Kaur. 1998. Gibberellic acid and kinetin partially reverse the effect of water stress on germination and seedling growth. Plant Growth Regul. 25: $29-33$.

Kaya, C., H. Kirnak and D. Higgs. 2001a. Enhancement of growth and normal growth parameters by foliar application of potassium and phosphorus on tomato cultivars grown at high $(\mathrm{NaCl})$ salinity. J. Plant Nutr. 24: 357- 367.

Kaya, C., H. Kirnak and D. Higgs. 2001b. the effects of supplementary potassium and phosphorus on physiological development and mineral nutrition of cucumber and pepper cultivars grown at high salinity $(\mathrm{NaCl})$. J. Plant Nutr. 24: 1457- 1471.

Khafagi, D.M.A. and W.I. El-Lawandy, 1996. Salt tolerance of sugar beet (Beta vulgaris, L.). I I. Metabolic products and ion accumulation. Annals of Agric. Sci., Moshtohor products, 34 (4): 1947 - 1663.

Mishra, A., M.A. Choudhuri, 1999. Effect of salicylic acid on heavy metal induced membrane deterioration mediated by lipoxygenase in rice. Biol.Plant., 42 (3): 409 - 415.

Nieman, R.H., 1962. Some effects of sodium chloride on growth, Photosynthesis and respiration of twelve crop plants. Bot. Gaz. 123: 279-285.

Plaut, Z., M. Edelstein and M. Ben-Hur. 2013. Overcoming salinity barriers to crop production using traditional methods. Critical Reviews in Plant Sci. 32: 250-291.

Shannon, M.C. 1998. Adaptation of plant to salinity. Adv. Agron. 60: 75-119.

Steduto, P., T. C. Hsiao, E. Fereres, and D. Raes. 2012. Crop yield response to water. FAO, Irrigation and Dreinage Paper, No. 66, Rome, 207.

Welbaum, G.E., T. Tissaoui and K.J. Bradford. 1990. Water relations of seed development and germination in muskmelon (Cucumis melo L.). III. Sensitivity of germination to water potential and abscisic acid during development, Plant Physiol. 92: 1029-1037. 


\section{الملخص العربي}

تأثير غمر بذور بنجر السكر في حامض الجبريلليك أوالأبسيسيك أوالأسكوربيك على خفض إجهاد

\section{الملوحة}

السيد عبد الرعوف عبداله

أدى إلى زيادة نسبة المجموع الخضري/الجذري على أساس

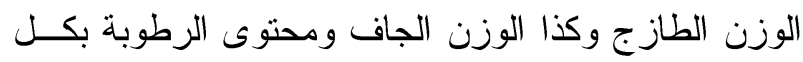

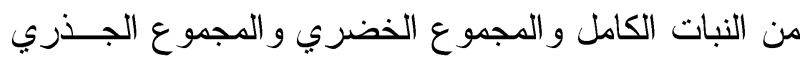

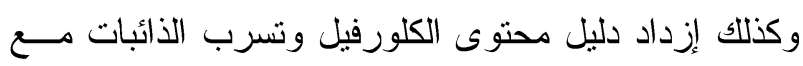

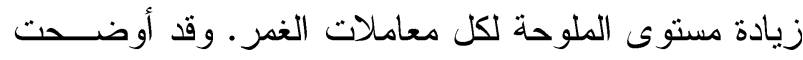

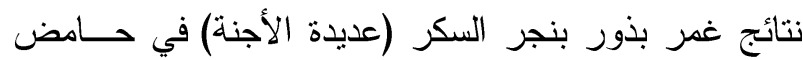

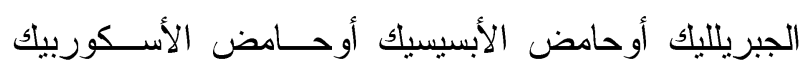

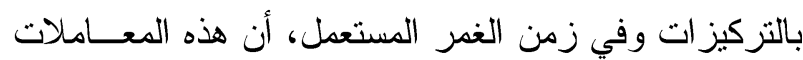

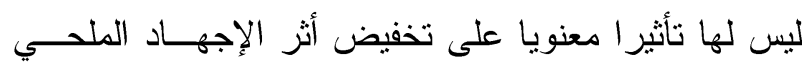

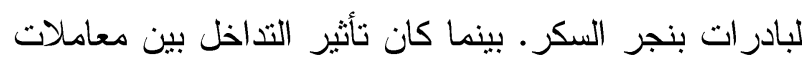

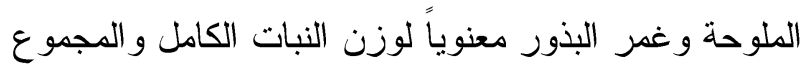

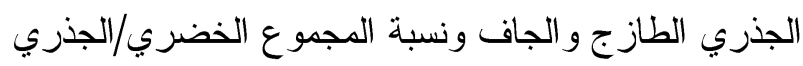
على أساس الوزن الطازج ومحتوى الرطوبة للنبات الكامل

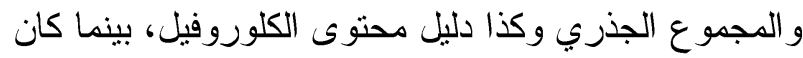

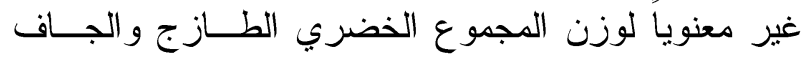

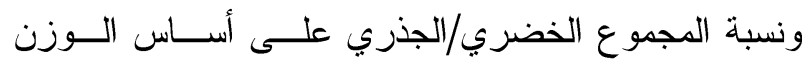

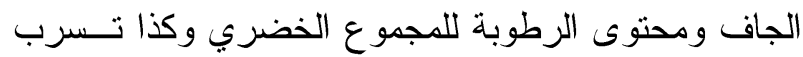

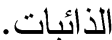

أجري هذا البحث للتعرف على تأثير غمر بذور بنجـر

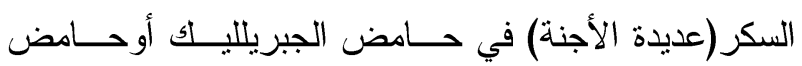
الأبسيسيك أوحامض الأسكوربيك على خفض الأنى ألثير الإجهاد

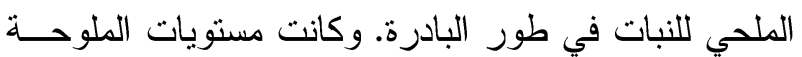

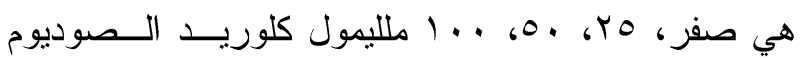

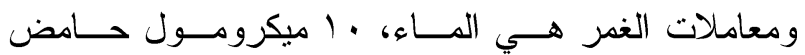

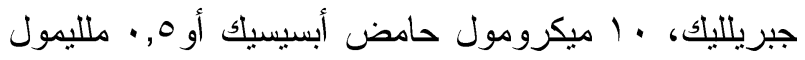

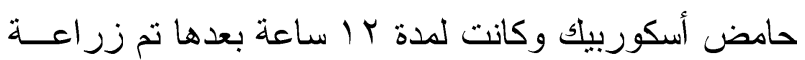

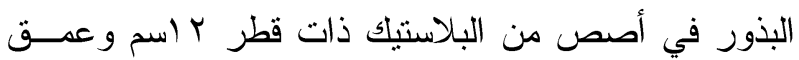

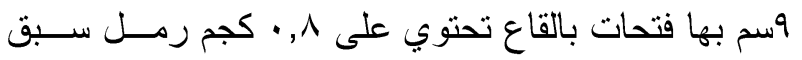

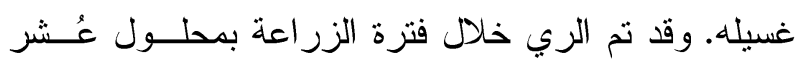

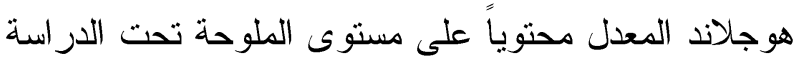

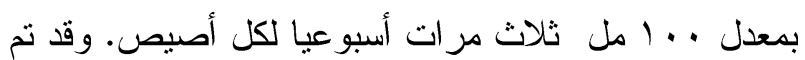

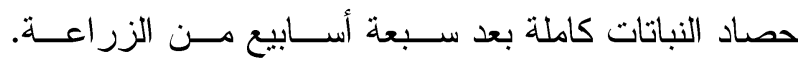

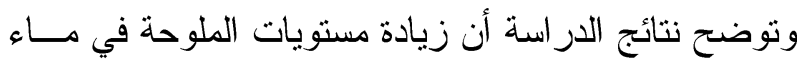

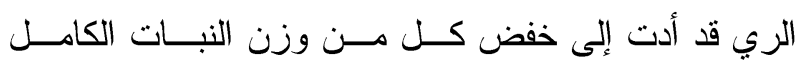

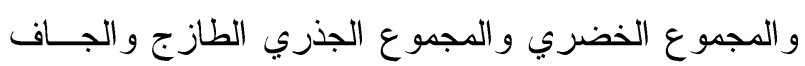
وكذا طول المجموع الخضري لكل معاملات الغمر ـ ولكـنـ 